\title{
The Degree of Practicing Resonant Leadership Among Kindergarten Female Principals in Gaza Governorates and Its Relation to Their Level of Organizational Virtuousness
}

\author{
Marawan W. Al-Masry
}

Al-Quds Open University - Gaza - Palestine

\begin{abstract}
This research aimed at identifying the degree of practicing resonant leadership among kindergarten female principals in Gaza governorates, and its relation to their level of organizational virtuousness, from the female kindergarten teachers point of view, by using the descriptive/ correlation approach and referring to previous literature review. A questionnaire was designed consisted of (58) items distributed on (8) axes: mindfulness, hope, compassion, organizational optimism, organizational trust, organizational compassion, organizational integrity and organizational forgiveness, and after verifying its validity and reliability, the questionnaire has been applied to a stratified random sample of (252) female kindergarten teachers. The research found that the degree of kindergarten female principals' practice of resonant leadership was "intermediate", and that the level of organizational virtuousness is also "intermediate", there was also revealed a positive correlation statistically significant at $(\alpha \leq 0.05)$ between the degree of practicing resonant leadership among kindergarten female principals in Gaza governorates and their level of organizational virtuousness. The research recommended the necessity of developing an integrated plan to spread the two cultures of resonant leadership and organizational virtuousness in kindergartens and organizing awareness meetings for kindergarten female principals to increase their knowledge of the two entrances to resonant leadership and organizational virtuousness and their impact on organizational development.
\end{abstract}

Keywords: Resonant Leadership; Organizational Virtuousness; Kindergartens; Gaza Governorates

Citation Al-Masry, M. The Degree of Practicing Resonant Leadership Among Kindergarten Female Principals in Gaza Governorates and Its Relation to Their Level of Organizational Virtuousness, SVU-Journal of abstract 2020, 2 (1): pp10 (retrieved from the SVUInternational Journal Of Educational Sciences,2020, No 5).

Copyright: Publisher South Valley University. This is an open access article distributed under the terms of the creative common attribution license, which permits unrestricted use, distribution and reproduction in any medium provided the original author and source are created. 
SVU- Journal of Abstracts, Volume (2), Issue (1): pp.8 2020

Print ISSN: 2682-2164

Online ISSN: 2682-2172

https://svuja.journals.ekb.eg/ 